\title{
Time-dependent Changes in the Density and Hemoglobin F Content of Biotin-Labeled Sickle Cells
}

\author{
Robert S. Franco, ${ }^{\star}$ Joni Lohmann, $\|$ Edward B. Silberstein, ${ }^{\star}$ Gayle Mayfield-Pratt, ${ }^{\star}$ Mary Palascak, ${ }^{\star}$ Therese A. Nemeth, ${ }^{\ddagger}$ \\ Clinton H. Joiner, ${ }^{\ddagger}$ Murray Weiner, ${ }^{*}$ and Donald L. Rucknagel ${ }^{\ddagger \S}$ \\ *University of Cincinnati College of Medicine, Cincinnati, Ohio 45267-0508; ${ }^{\ddagger}$ Children’s Hospital Research Foundation, ${ }^{\S}$ Cincinnati \\ Comprehensive Sickle Cell Center, Cincinnati, Ohio 45229-3039; and ${ }^{\|}$Cincinnati Veterans Administration Medical Center, Cincinnati, \\ Ohio 45220
}

\begin{abstract}
Sickle red blood cells (RBC) are subject to a number of important cellular changes and selection pressures. In this study, we validated a biotin $\mathrm{RBC}$ label by comparison to the standard ${ }^{51} \mathrm{Cr}$ label, and used it to study changes that occur in sickle cells as they age. Sickle RBC had a much shorter lifespan than normal RBC, but the two labels gave equivalent results for each cell type. A variable number of sickle, but not normal, RBC disappeared from the circulation during the first few hours after reinfusion. The number of biotinylated sickle reticulocytes was decreased by $50 \%$ after $24 \mathrm{~h}$ and $75 \%$ after $48 \mathrm{~h}$, with a gradual decrease in the amount of reticulum per cell. The labeled sickle cells exhibited major density increases during the first 4-6 d after reinfusion, with smaller changes thereafter. A small population of very light, labeled sickle RBC was essentially constant in number after the first few days. Fetal hemoglobin (HbF) content was determined in isolated biotinylated sickle $\mathrm{RBC}$ after reinfusion, allowing an estimate of lifespan for $\mathrm{RBC}$ containing $\mathrm{HbF}$ ( $\mathrm{F}$ cells) and non-F cells. The lifespan of sickle biotinylated RBC lacking $\mathrm{HbF}$ was estimated to be $\sim 2 \mathrm{wk}$, whereas F cells survived 6-8 wk. (J. Clin. Invest. 1998. 101: 2730-2740.) Key words: red blood cell $\bullet$ sickle cell disease • biotin $\bullet$ red cell survival $\bullet$ flow cytometry
\end{abstract}

\section{Introduction}

Normal red blood cells (RBC) ${ }^{1}$ progress through several stages in the circulation, including a short period as reticulocytes, a long period as mature RBC with remarkably stable and homogeneous properties, and a terminal, senescent state that is most likely of short duration. Under normal circumstances, human erythroid cells released from the marrow at the same time go through these stages together, and have a relatively narrow range of survival times. Progression from the reticulocyte to a

This research has been presented in part in abstract form. R.S. Franco, J. Lohmann, E.B. Silberstein, G. Mayfield-Pratt, D.L. Rucknagel, C.H. Joiner, and M. Weiner. 1996. Blood. 88:11a(Abstr.).

Address correspondence to Dr. Robert S. Franco, Ph.D., Research Professor, Division of Hematology/Oncology, Mail Location \#508, University of Cincinnati College of Medicine, 231 Bethesda Avenue, Cincinnati, OH 45267-0508. Phone: 513-558-3241; FAX: 513558-6703; E-mail: Robert.Franco@uc.edu

Received for publication 11 December 1997 and accepted in revised form 26 March 1998.

The Journal of Clinical Investigation

Volume 101, Number 12, June 1998, 2730-2740

http://www.jci.org mature $\mathrm{RBC}$ is associated with a modest decrease in volume and resultant density increase (1), presumably because of loss of intracellular monovalent cation. Some normal RBC $(<5 \%)$ contain fetal hemoglobin $(\mathrm{HbF})$ in addition to adult hemoglobin (HbA) and are called F cells.

In sickle cell anemia, RBC survival is shorter and more complex. There is a population of abnormally dense, dehydrated, K-depleted RBC that varies in size among patients and during painful episodes in individual patients (2). In 1968, Bertles and Milner (3) used an isotopic cohort label to show that at least some sickle cells become dense within a few days after leaving the marrow. This is supported by the presence of reticulocytes and transferrin-receptor-positive cells in the denser RBC fractions (4). However, sickle RBC that contain HbF appear to be spared from severe early dehydration (4). Sicklecell patients in general have much higher levels of $\mathrm{HbF}$ than normal subjects, and in each patient the percentage of mature sickle RBC containing $\mathrm{HbF}$ is two to four times higher than the percentage of reticulocytes with $\operatorname{HbF}(4,5)$. Based on this indirect evidence, it has been concluded that $\mathrm{F}$ cells have a longer survival in the circulation than RBC lacking $\mathrm{HbF}$ (5). This conclusion is supported by an improvement in RBC survival after the percentage of $\mathrm{F}$ cells is increased by treatment with hydroxyurea (6).

The standard label for erythrocyte survival studies is ${ }^{51} \mathrm{Cr}$, which binds tightly but noncovalently to hemoglobin. An alternative nonisotopic label is the covalent attachment of biotin to red cell membrane proteins, with detection by means of fluorochrome-conjugated streptavidin (SA) and flow cytometry. Dale and colleagues (7-13) established the biotin method for evaluation of RBC senescence in rabbits, and Russo et al. (14) used flow cytometry to demonstrate normal long-term survival for biotin-labeled RBC (B-RBC) in rabbits. Similar studies in mice (15) and dogs (16) have confirmed the utility of B-RBC for in vivo red cell tracking. Cavill et al. (17) used RBC labeled with both biotin and ${ }^{51} \mathrm{Cr}$ to measure red cell volume in $19 \mathrm{hu}-$ man subjects, and found no difference between the labels. The biotinylation reagent used in that study (17) inserted a fivecarbon spacer between biotin and the target membrane proteins, making it relatively unstable in the circulation (17) and inappropriate for measuring long-term RBC survival.

In the studies reported here, we compare RBC survival characteristics, measured with a biotin label lacking the spacer and a concurrent ${ }^{51} \mathrm{Cr}$ label in normal volunteers and patients

1. Abbreviations used in this paper: $\mathrm{B}-\mathrm{RBC}$, biotinylated red blood cells; D-PBS, Dulbecco's PBS; DS, density score; F cells, RBC containing $\mathrm{HbF}$; $\mathrm{Fx}$, fraction; $\mathrm{HbF}$, fetal hemoglobin; $\mathrm{HbA}$, adult hemoglobin; HbS, hemoglobin S; Hct, hematocrit; $\mathrm{MCH}$, mean corpuscular hemoglobin; NHS-biotin, $N$-hydroxysuccinimido biotin; PE, phycoerythrin; RBC, red blood cells; SA, streptavidin; TfR, transferrin receptor. 
NORMAL

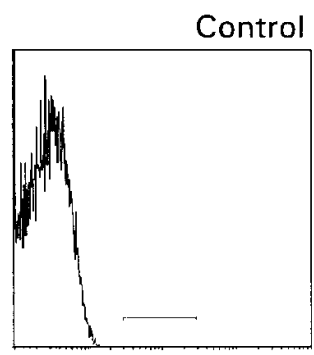

Pre-Infusion

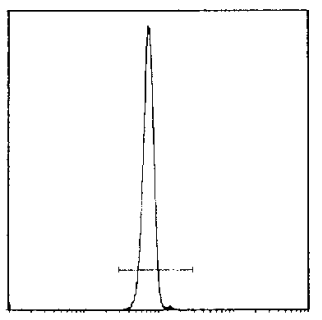

10 Minutes Post

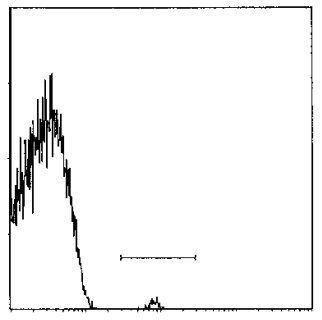

24 Hours Post

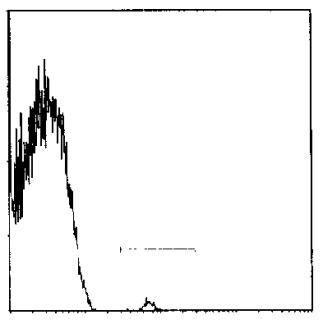

10 Days Post

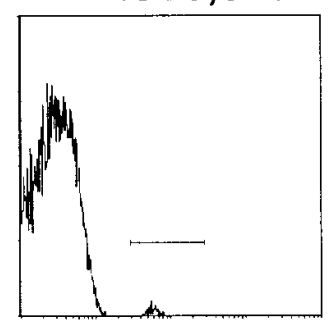

SICKLE

Control

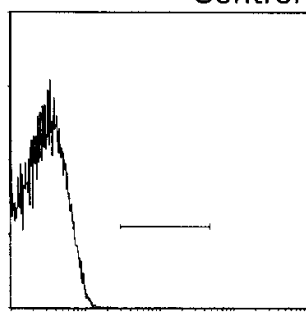

Pre-Infusion

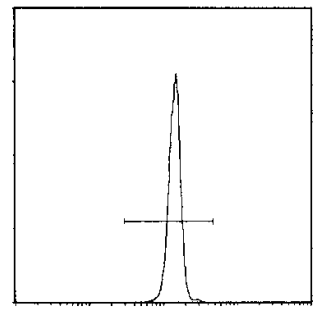

15 Minutes Post

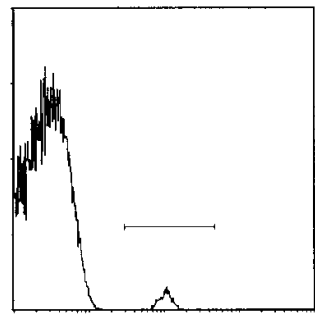

24 Hours Post

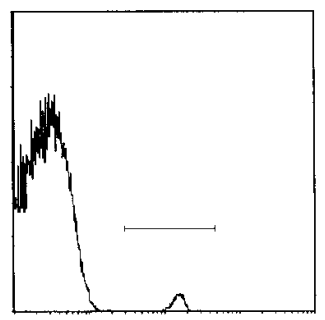

16 Days Post

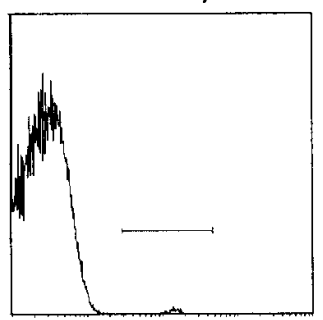

Figure 1. Flow cytometric analysis of biotin-labeled RBC. Red blood cells from normal volunteers and sickle-cell patients were biotinylated (B-RBC) and reinfused. The percentage of B-RBC in postinfusion blood samples was determined by flow cytometry after reaction with SA-PE. The $x$-axis represents log-fluorescent intensity of PE;

with sickle-cell anemia, and show that both labels give equivalent results. Further studies used the biotin label to measure sickle reticulocyte survival, to investigate time-dependent sickle RBC density changes in the circulation, and to measure the survival advantage of HbF-containing sickle RBC.

\section{Methods}

Cell labeling. Hematologically normal volunteers and patients with homozygous sickle-cell anemia were studied with informed consent in accordance with a protocol approved by the University of Cincinnati Institutional Review Board. All studies used autologous RBC, and patients with sickle cell disease had not had a recent transfusion or painful episode. Blood was drawn into $15 \mathrm{U} / \mathrm{ml}$ heparin, labeled under aseptic conditions, and reinfused on the same day. For labeling with biotin, blood equivalent to $5-10 \mathrm{ml}$ packed RBC was washed three times with at least 2 vol of Dulbecco's PBS (D-PBS; \#14190045; Gibco BRL, Gaithersburg, MD), transferred to a $175-\mathrm{ml}$ tube (3145-0175; Nalgene, Rochester, NY), and adjusted to 7\% hematocrit. A stock solution containing $2 \mathrm{mg} / \mathrm{ml} N$-hydroxysuccinimido biotin (NHS-biotin) in 10\% DMSO was prepared by dissolving $10 \mathrm{mg}$ NHS-biotin (H1759FD; Sigma Chemical Co., St. Louis, MO) in 0.5-ml DMSO (Cryoserv; Research Industries Corp., Midvale, UT), followed by addition of $4.5 \mathrm{ml}$ D-PBS. This solution was sterilized by filtration through a $0.2-\mu \mathrm{m}$ syringe filter (21062-25; Corning Glassware, Corning, NY) made from DMSO-resistant materials. The appropriate volume of NHS-biotin stock solution was added with gentle agitation to the $7 \% \mathrm{RBC}$ suspension to give the desired final concentration of NHS-biotin (e.g., $0.5 \mu$ l of stock solution per milliliter of RBC suspension to give $1 \mu \mathrm{g} / \mathrm{ml}$ ). After a 30 -min incubation at room temperature, the cells were washed four times with at least $3 \mathrm{vol}$ of D-PBS. Red cell biotinylation was confirmed as described below and an accurate suspension volume and $\mathrm{RBC}$ count were obtained to give the total number of B-RBC. From this point, care was taken to avoid any cellular losses. In two experiments with normal RBC (subjects N1 and N2) the same $\mathrm{RBC}$ were also labeled with ${ }^{51} \mathrm{Cr}$ according to a standard protocol (18). In five experiments, two with normal RBC (N3 and N4) and three with sickle RBC (S1-S3), an aliquot of nonbiotinylated RBC (non-B-RBC) was labeled with ${ }^{51} \mathrm{Cr}$, mixed with the $\mathrm{B}-\mathrm{RBC}$, and given two final washes with injectable saline before reinfusion. In four experiments with sickle RBC (S4-S7), only the biotin label was used. The cells, at a hematocrit of $\sim 50 \%$, were infused through an 18- $\mu \mathrm{m}$ filter (Hem-O-Nate; Bard, Salt Lake City, UT) that was then flushed with saline to insure all cells were infused.

Blood sampling and flow cytometric analysis. For normal volunteers, blood samples were taken into EDTA at 5, 7.5, 10, 12.5, 15, 20, and $60 \mathrm{~min}, 24,48$, and $72 \mathrm{~h}$, and periodically thereafter until the level of labeled cells was less than one-half the postinfusion value. For patients with sickle-cell disease, the sampling schedule varied and is indicated in the text and figures. A 1-ml aliquot was counted for ${ }^{51} \mathrm{Cr}$ in studies that included this label. For analysis of B-RBC, $80 \mu \mathrm{l}$ of a $1 \%$ RBC suspension was mixed with $20 \mu l$ of a 1:20 dilution (in PBS) of streptavidin-phycoerythrin (SA-PE; S-866; Molecular Probes, Eugene, OR), and incubated $30 \mathrm{~min}$ at room temperature. After two washes with PBS, the cells were resuspended to $400 \mu l$ with PBS and $600 \mu \mathrm{l}$ of $1.25 \%$ paraformaldehyde fixative (14) was added. In some experiments with sickle-cell patients, the washed PE-labeled cells (without fixation) were divided into two portions, and one aliquot was suspended in $1 \mathrm{ml}$ of a solution of thiazole orange (Becton Dick-

the $y$-axis represents the relative number of cells. Before reinfusion, essentially all the RBC were biotinylated (preinfusion). After reinfusion the fluorescent intensity of the small positive peak of B-RBC was nearly constant for many weeks in the circulation, indicating that the biotin label was stable. 


\begin{tabular}{|c|c|c|c|c|c|c|c|c|c|}
\hline & \multirow[b]{2}{*}{$\mu \mathrm{g} / \mathrm{ml}^{*}$} & \multirow[b]{2}{*}{ Label type ${ }^{\ddagger}$} & \multicolumn{2}{|c|}{ Blood volume } & \multicolumn{2}{|c|}{ 24-h survival } & \multicolumn{2}{|c|}{ (Long-term survival) } & \\
\hline & & & ${ }^{51} \mathrm{Cr}$ & Biotin & ${ }^{51} \mathrm{Cr}$ & Biotin & ${ }^{51} \mathrm{Cr}$ & Biotin & \\
\hline & & & \multicolumn{2}{|c|}{$m l$} & \multicolumn{2}{|c|}{$\%$} & \multicolumn{2}{|c|}{$d$} & \\
\hline N1 & 5 & S & & & 102 & 97 & 68 & 67 & Lifespan \\
\hline $\mathrm{N} 2$ & 1 & S & & & 94 & 101 & 140 & 105 & Lifespan \\
\hline N3 & 1 & $\mathrm{D}$ & 3892 & 4443 & 96 & 98 & 108 & 120 & Lifespan \\
\hline N4 & 3 & $\mathrm{D}$ & 4917 & 5427 & 96 & 99 & 85 & 90 & Lifespan \\
\hline S1 & 1 & $\mathrm{D}$ & 6578 & 6259 & 101 & 92 & 13.5 & 13.5 & $50 \%^{\S}$ \\
\hline S2 & 3 & $\mathrm{D}$ & 6880 & 6228 & 85 & 79 & 11 & 9.5 & $50 \%$ \\
\hline S3 & 3 & $\mathrm{D}$ & 6760 & 5800 & 68 & 75 & 8.5 & 7.5 & $50 \%$ \\
\hline Average & & & 5805 & 5631 & 89.2 & 88.6 & & & \\
\hline$P$, paired $t$ test $\|^{\|}$ & & & & & & & & & \\
\hline
\end{tabular}

*Concentration of NHS-biotin during red blood cell biotinylation incubation. *The two labels were placed either on the same $(S)$ or different $(D)$ cells. ${ }^{\circledR}$ The survival curves for sickle-cell patients are not linear, and the time for removal of $50 \%$ of the RBC from the circulation is given. Includes only experiments with the biotin and ${ }^{51} \mathrm{Cr}$ labels on different RBC.

inson Co., Mountain View, CA) and incubated for $30 \mathrm{~min}$ in the dark to stain reticulocytes. This two-color analysis allowed the percentage of reticulocytes to be evaluated at various time points for both the reinfused (PE-positive) B-RBC and all the RBC in the circulation. Cells were analyzed by flow cytometry in log-fluorescence histograms (XL-MCL; Coulter Immunology Corp., Hialeah, FL) after selection in a red cell forward-vs.-side light-scatter region. Before reinfusion, the B-RBC were analyzed to insure that at least $99 \%$ of the cells were positive for biotin and that there was baseline separation on the flow cytometric histogram between the B-RBC and the non-B-RBC. For
non-B-RBC, the number of events in the region used to enumerate $\mathrm{B}-\mathrm{RBC}$ was negligible.

Analysis of RBC survival data. We compared immediate survival of RBC by calculating blood volume on the basis of the dilution of each label, according to the formulas shown below (19). If the ratio of total infused label to the blood concentration of label at the extrapolated time zero (the calculated blood volume) is the same for the ${ }^{51} \mathrm{Cr}$ and biotin labels, then the immediate survival of the biotin label is shown to be as good as the ${ }^{51} \mathrm{Cr}$ label. The two labels must be on different cells for this analysis to be valid, and ideally should be evalu-
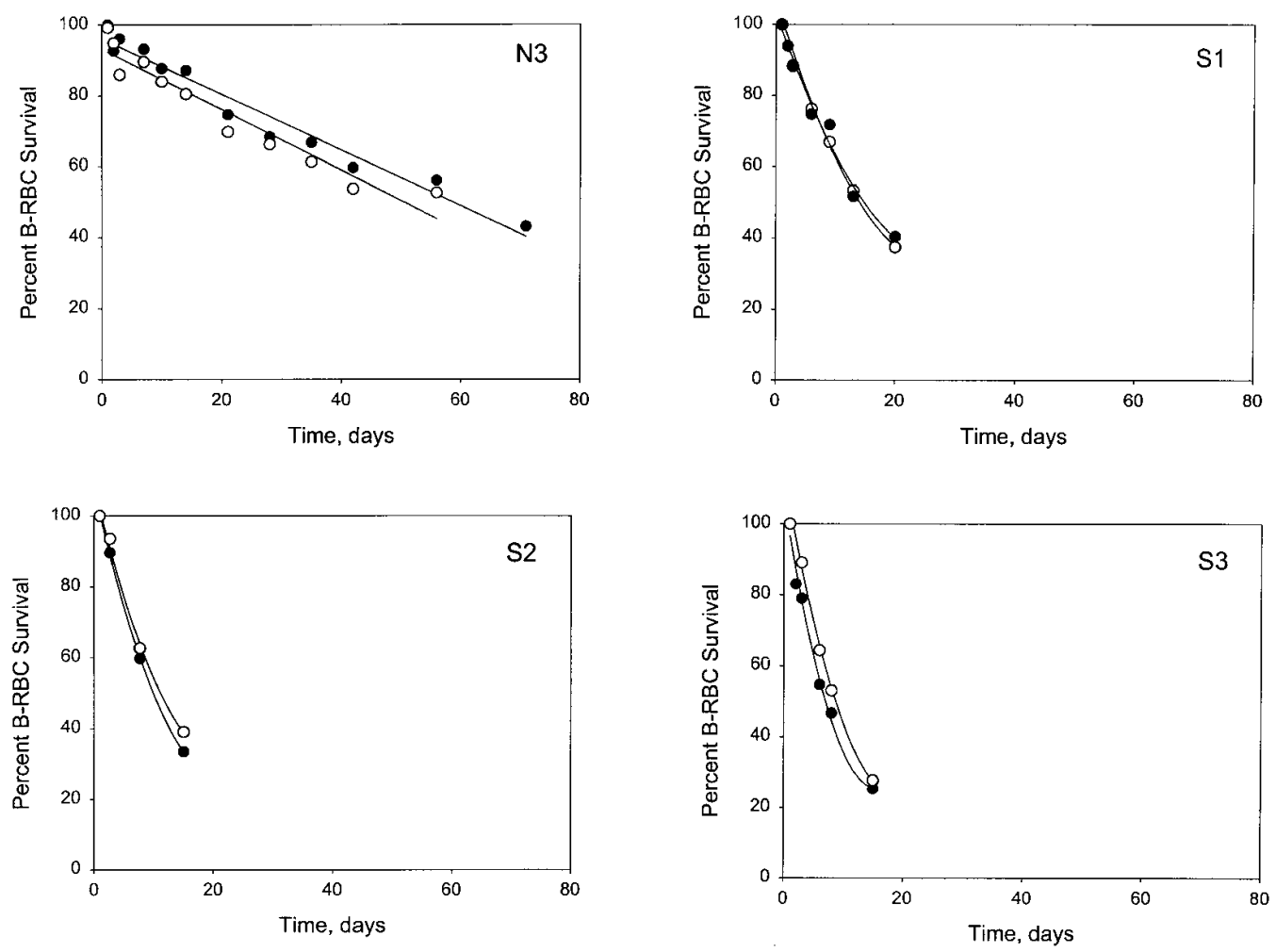

Figure 2. Lifespan of normal and sickle RBC labeled with biotin or ${ }^{51} \mathrm{Cr}$. Separate aliquots of autologous normal (N3) or sickle (S1-S3) RBC were labeled with biotin or ${ }^{51} \mathrm{Cr}$ and reinfused. Longterm survival was determined by comparing the amount of label, either percent B-RBC $(\bullet)$ or counts per minute per milliliter (o), with a $100 \%$ reference measured the first day after reinfusion. 
ated concurrently. The ratio of whole body hematocrit to venous hematocrit was assumed to be 0.91 in these calculations (19). This ratio is valid for normal individuals, but varies in anemia and other disease states (19). However, any discrepancy from this value will be identical for both labels.

$B V_{\mathrm{Cr}}=\operatorname{Total} /\left(T_{0} \times 0.91\right)$

$B V_{\text {Biot }}=N /\left(R B C \times f_{0} \times 0.91\right)$

where Total $=$ total counts per minute infused; $T_{0}=$ counts per minute at time zero per milliliter, extrapolated from 5-20-min time points; $N=$ total number of B-RBC infused; $R B C=$ number of circulating RBC per milliliter of blood at time of reinfusion; $f_{0}=$ fraction B-RBC at time zero, extrapolated from 5-20-min time points.

The 24-h survival was calculated by dividing the counts per minute per milliliter or percentage of B-RBC in blood after $24 \mathrm{~h}$ by the corresponding extrapolated value at time zero. An exception was subject S1, for whom the 60-min point was used as reference for the 24-h survival. The total RBC count was monitored during each experiment and remained stable. The 24 -h value was used as the $100 \%$ reference for long-term survival, since in some sickle-cell patients a sizable population of RBC disappeared from the circulation during the first few hours after reinfusion (see below). However, when the survivals of $\mathrm{F}$ and non-F cells were compared (see below), the time zero values were used as the $100 \%$ reference. The long-term ${ }^{51} \mathrm{Cr}$ data were corrected for elution, whereas no correction was necessary for B-RBC.

Density fractionation. To follow the hydration changes that take place in vivo, postinfusion blood samples (subjects S4-S7) were separated into six density fractions using discontinuous arabinogalactan gradients. Arabinogalactan solutions with densities of 1.073, 1.083, $1.090,1.094$, and $1.10 \mathrm{~g} / \mathrm{cc}$ were prepared by dilution of a commercial concentrate (Cellsep; Larex, Inc., St. Paul, MN) according to the manufacturer's directions. Discontinuous gradients were prepared with $2 \mathrm{ml}$ of each density layer in $14 \times 89 \mathrm{~mm}$ polyallomer ultracentrifuge tubes, and overlayered with $1.5 \mathrm{ml}$ of washed cell suspension $(\mathrm{Hct}=25 \%)$. Gradients were centrifuged $\left(20,000 \mathrm{rpm}, 45 \mathrm{~min}, 22^{\circ} \mathrm{C}\right.$, SW41 rotor; Beckman Inc., Fullerton, CA), and six fractions removed (Fx 1: < 1.073; Fx 2: 1.073-1.083; Fx 3: 1.083-1.090; Fx 4: 1.090-1.094; Fx 5: 1.094-1.100; Fx 6: > 1.100). The cells in each fraction were washed with PBS, brought to $1 \mathrm{ml}$, and sampled for cell counts (CBC-5; Coulter Immunology Corp.). Each fraction was again centrifuged, the supernatant was removed, and $10 \mu \mathrm{l}$ of the well-mixed pellet was removed for staining and flow cytometry as described above. The density distributions of non-B-RBC and B-RBC were calculated from the cell count in each fraction and the percentage of $\mathrm{B}-\mathrm{RBC}$ in each fraction. The absolute number of B-RBC in each fraction (per 10,000 cells loaded onto the gradient) was also derived for each postinfusion time point. A density score (DS) was calculated analogous to that previously used (20), except that six fractions were used rather than four. The DS is a weighted sum that ranges from 100 (all cells in Fx 1) to 600 (all cells in Fx 6), and gives a numerical value to the density distribution.

Magnetic bead isolation of B-RBC and HPLC analysis of $H b F$. Biotinylated RBC were isolated from postinfusion blood samples using streptavidin-coated magnetic beads (Dynal, Great Neck, NY) as previously described (14). Flow cytometric analysis of the cell suspension before and after exposure to magnetic beads indicated that approximately one-half of the B-RBC were recovered. Since the amount of biotin on the B-RBC is quite uniform and stable during the experiment, incomplete recovery is most likely a stochastic rather than a systematic phenomenon, and the recovered cells should be representative of the entire B-RBC population.

The magnetic bead/B-RBC aggregates were centrifuged, the supernatant removed, and the pellets frozen at $-20^{\circ} \mathrm{C}$. At the time of analysis, the pellets were thawed, $100 \mu \mathrm{l}$ of water was added, two additional freeze-thaw cycles were performed, and the magnetic beads were removed by centrifugation. The lysate was analyzed by ion- exchange HPLC, and $(\mathrm{HbF} /[\mathrm{HbF}+\mathrm{HbS}])$ was calculated for each postinfusion sample. Control samples for HPLC analysis at each time point were also prepared from the cells remaining after isolation of the B-RBC.

Separate estimates of the lifespan of F cells and non-F cells may be calculated from the overall RBC survival curve, the postinfusion percentage of $\mathrm{HbF}$ in the $\mathrm{B}-\mathrm{RBC}$, and $\mathrm{HbF}$ per $\mathrm{F}$ cell. The latter was derived for each patient from the percent $\mathrm{HbF}$ and the percent $\mathrm{F}$ cells (see below) in blood. As a hypothetical example, if initially $\mathrm{HbF}$ is $10 \%$ of total $\mathrm{Hb}$ and $\mathrm{F}$ per $\mathrm{F}$ cell is $11 \mathrm{pg}$, then $\sim 30 \%$ of the cells are $\mathrm{F}$ cells (mean corpuscular hemoglobin $[\mathrm{MCH}]=33 \mathrm{pg}$ ). For each 1,000 cells infused, there would be $300 \mathrm{~F}$ cells and 700 non-F cells. If after $5 \mathrm{~d}$ the $\mathrm{HbF}$ in $\mathrm{B}-\mathrm{RBC}$ is $15 \%$, then $45 \%$ are $\mathrm{F}$ cells. If the overall survival at $5 \mathrm{~d}$ is $60 \%$, then there are 600 total cells, $270 \mathrm{~F}$ cells, and 330 non-F cells. Therefore, after $5 \mathrm{~d}$ the fractional survivals would be $(270 / 300)=0.9$ for $F$ cells and $(330 / 700)=0.47$ for non-F cells. This analysis assumes that all $\mathrm{F}$ cells contain the same amount of $\mathrm{HbF}$.

Flow cytometric analysis of $\mathrm{HbF}$-containing $\mathrm{RBC}$. The percentage of $\mathrm{F}$ cells was determined in four patients (S4-S7) by flow cytometry (21). After two washes, the cells were resuspended in $892 \mu \mathrm{l}$ of PBS and $108 \mu \mathrm{l}$ of $37 \%$ formaldehyde was added. After $1 \mathrm{~h}, 250 \mu \mathrm{l}$ of $0.05 \%$ glutaraldehyde was added, and the suspension was incubated for $2 \mathrm{~min}$. After one wash with PBS, the pellet was resuspended to $500 \mu \mathrm{l}$ with PBS/0.01\% Triton X-100/0.1\% BSA and $7.1 \mu \mathrm{l}$ of $0.7 \mathrm{mg} / \mathrm{ml}$ FITC-anti HbF (Isolab, Inc., Akron, OH) was added. After a 30-min incubation, the RBC were washed once with PBS and the percentage of fluorescent $F$ cells was determined. The $F$ per $F$ cell was calculated from the percent $\mathrm{F}$ cells, the percent $\mathrm{HbF}$ (determined by HPLC), and the $\mathrm{MCH}$, using the formula shown in Table II.

\section{Results}

Comparison of red cell survival using concurrent biotin and ${ }^{51} \mathrm{Cr}$ labels. The biotinylation method used in these studies, with NHS-biotin concentration from 1 to $5 \mu \mathrm{g} / \mathrm{ml}$, gave essentially $100 \%$ positive red cells (Fig. 1, preinfusion). After reinfusion, $\mathrm{B}-\mathrm{RBC}$ ranged from 0.36 to $0.85 \%$ of the total $\mathrm{RBC}$. Initial studies (subjects N1 and N2, Table I) with both labels on the same RBC were performed primarily to demonstrate

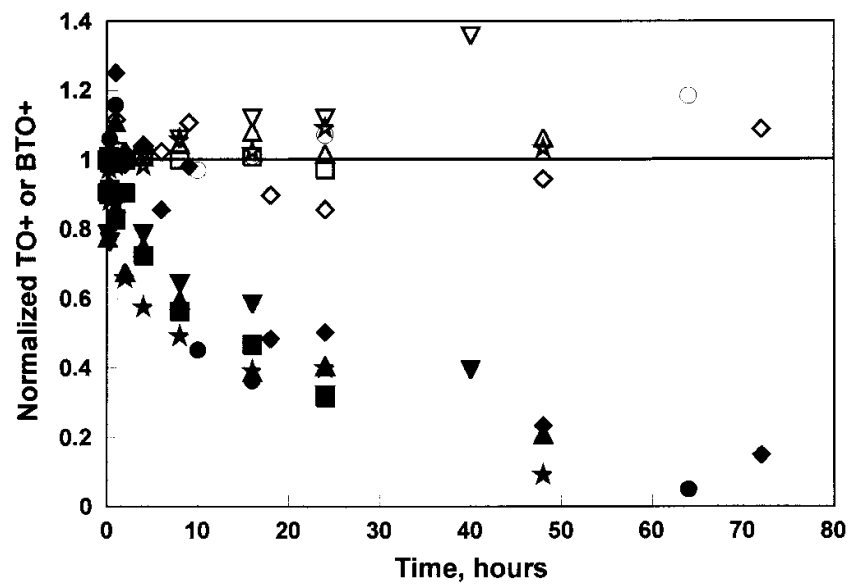

Figure 3. In vivo disappearance of biotin-labeled sickle reticulocytes. Biotinylated reticulocytes for six sickle cell patients were enumerated, and their rate of disappearance from the circulation determined. Open symbols, numbers of unlabeled reticulocytes, which remain constant as expected. Closed symbols, corresponding biotinylated reticulocytes. All percentages were normalized, using the number of unlabeled reticulocytes at the time of reinfusion as $100 \%$. 

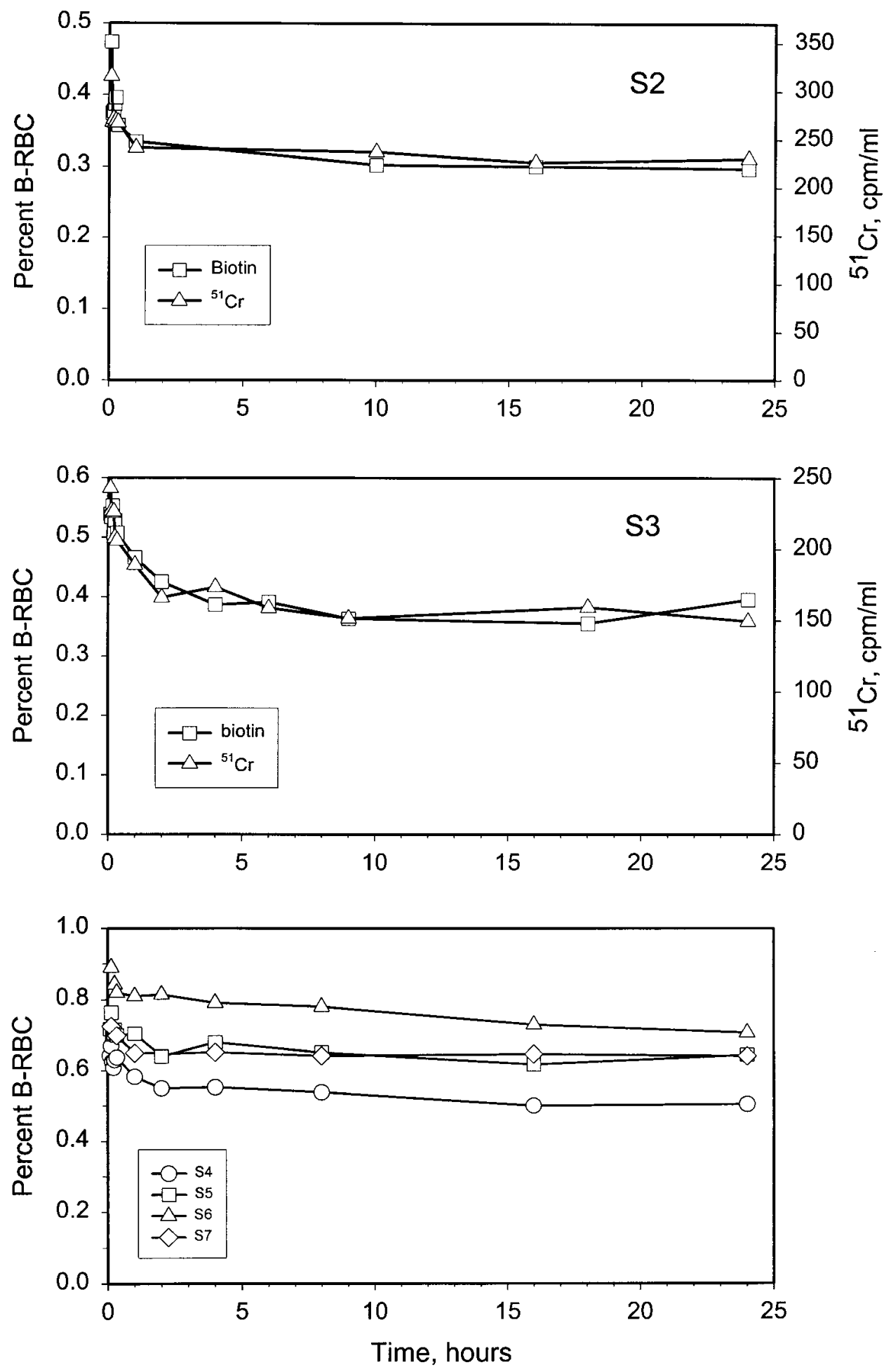

Figure 4. Removal of labeled sickle $\mathrm{RBC}$ from the circulation during the first $24 \mathrm{~h}$ after reinfusion. Top and center, initial removal of biotin- and ${ }^{51} \mathrm{Cr}$-labeled sickle RBC (labels on separate cells, studied concurrently) in two patients. Bottom, the biotin label only for additional sickle cell reinfusions. A variable number of sickle cells are removed from the circulation for both labels during the first few hours after reinfusion. In normal subjects, there was little or no loss of either label during the first $24 \mathrm{~h}$ (Table I).

the long-term stability of the biotin label. Since survival with both labels was similar (Table I), these studies showed that the biotin label is stable for the life of the cell.

The blood volumes calculated from the two labels (on separate cells) did not differ significantly when the data from normal volunteers and sickle-cell patients were pooled (Table I). For the two normal volunteers, however, the average blood volume calculated from the biotin data was $\sim 10 \%$ higher. For the three sickle-cell patients, it was $\sim 10 \%$ lower. Since a lower calculated blood volume implies better immediate recovery of the labeled cells, the biotin label gave the same or slightly better immediate recovery for sickle cells when compared with ${ }^{51} \mathrm{Cr}$.

The 24-h survival for RBC with each label, compared with the value immediately after infusion, indicated at least $94 \%$ survival for the ${ }^{51} \mathrm{Cr}$ label and $97 \%$ survival for the biotin label 


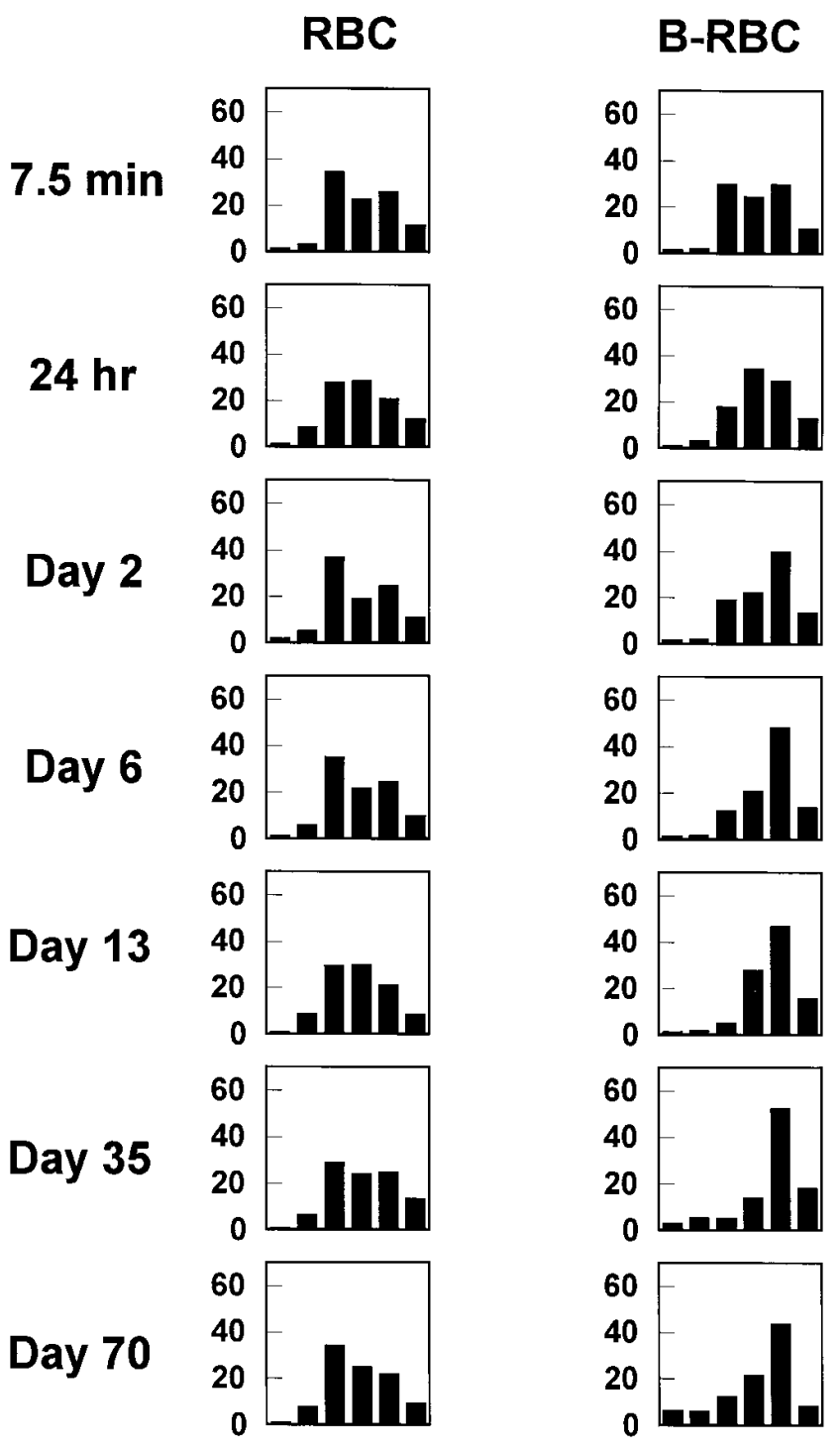

Figure 5. In vivo density changes of biotin-labeled sickle RBC. Postinfusion blood samples were separated into six density fractions, and the percentages of all unlabeled RBC and all remaining B-RBC in each fraction were determined. The density distribution of unlabeled $\mathrm{RBC}$ remained constant as expected for a patient in steady state. The density distribution of B-RBC shifted toward more dense cells during the first few days. Data are for patient S5. in the normal volunteers (Table I). For the two normal subjects in whom the labels were on separate cells, N3 and N4, the 24-h survivals agree within $3 \%$. For sickle-cell patients, the 24-h survival was more variable among patients, but in all patients there was good agreement between the two labels (Table I).

During long periods in the circulation, the normal and sickle B-RBC retained all or most of the biotin label, as shown by the intensity of the fluorescent label (Fig. 1). Because of the nature of the flow cytometric analysis, small changes in the intensity of labeling with time (for example, a minor decrease in the number of biotins per cell) had no effect on the percentage of positive cells. The highest concentration of biotin, $5 \mu \mathrm{g} / \mathrm{ml}$, was used in the first normal study (N1). These cells had a clearly decreased long-term survival of between 65 and $70 \mathrm{~d}$ for both labels (Table I). In this experiment, both labels were on the same cells, and the most likely cause of the shortened survival is the higher level of biotinylation. Biotinylation at $1 \mu \mathrm{g} / \mathrm{ml}$ NHS-biotin gave normal long-term survival (N2 and N3). In one normal subject (N4) labeled with $3 \mu \mathrm{g} / \mathrm{ml}$ NHSbiotin, the long-term survival was slightly decreased (90 d), but the concurrent and separate ${ }^{51} \mathrm{Cr}$-labeled cells gave a similar result $(85 \mathrm{~d})$, indicating that the biotin value is accurate for this subject and was not responsible for the shortened survival.

For all normal subjects, biotinylated RBC followed a linear disappearance curve with no need for correction. An example of normal RBC survival (N3) is shown in Fig. 2. The long-term survival of sickle cells (S1-S3) was more variable and these cells disappeared in a nonlinear manner (Fig. 2). There was good agreement in long-term RBC survival for the two labels in all patients, at both 1 and $3 \mu \mathrm{g} / \mathrm{ml}$ NHS-biotin (Table I and Fig. 2).

In vivo maturation and removal of biotinylated sickle reticulocytes. In six patients with sickle-cell disease (S2-S7), the disappearance of reticulocytes from the circulation was followed. There was a time-dependent decrease in the number of biotinpositive reticulocytes, and also the expected decrease in the amount of fluorescence per reticulocyte as the cells age (data not shown). Fig. 3 shows the number of biotin-labeled and unlabeled reticulocytes at various times after reinfusion, expressed relative to the number of reticulocytes in the blood at the time of reinfusion. The unlabeled reticulocytes remain constant, representing the steady-state reticulocyte count of the patient. The decrease in the biotin-labeled reticulocytes may reflect removal from the circulation of very young cells as well as maturation into red blood cells. In these six patients,

Table II. Cellular Characteristics for Studies Using the Biotin Label to Follow Time-dependent Changes in RBC Density and $\mathrm{HbF}$ Content

\begin{tabular}{|c|c|c|c|c|c|c|c|c|}
\hline & \multirow[b]{2}{*}{$\operatorname{HbF}(\%) *$} & \multirow[b]{2}{*}{$\mathrm{F}$ cells $(\%)$} & \multirow[b]{2}{*}{$\mathrm{MCH}$ (pg/cell) } & \multirow[b]{2}{*}{$\mathrm{HbF} / \mathrm{F}$ cell $(\mathrm{pg})^{\ddagger}$} & \multirow[b]{2}{*}{$\mathrm{TfR}^{+}(\% \mathrm{HbF})^{\S}$} & \multirow[b]{2}{*}{ 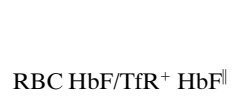 } & \multicolumn{2}{|c|}{ RBC survival } \\
\hline & & & & & & & $(24 \mathrm{~h}[\%])$ & $(\text { Long-term }[\mathrm{d}])^{\mathrm{T}}$ \\
\hline S4 & 20.7 & 60 & 34.1 & 11.8 & 6.5 & 3.2 & 79 & 25 \\
\hline S5 & 20.2 & 62 & 33.8 & 11.0 & 4.7 & 4.3 & 90 & 17 \\
\hline S6 & 7.0 & 29 & 32.9 & 7.9 & 1.5 & 4.7 & 83 & 11 \\
\hline S7 & 5.3 & 34 & 33.5 & 5.2 & 1.8 & 2.9 & 90 & 10 \\
\hline
\end{tabular}

In these studies $\mathrm{RBC}$ were labeled with $3 \mu \mathrm{g} / \mathrm{ml}$ biotin. $*(\mathrm{HbF} /[\mathrm{HbF}+\mathrm{HbS}]) \times 100$; determined on same samples as $\mathrm{F}$ cells. ${ }^{\ddagger} \mathrm{HbF} / \mathrm{F}$ cell $=(\% \mathrm{HbF} / \%$ $\mathrm{F}$ cells $) \times \mathrm{MCH}$; this assumes that $\mathrm{F}$ cells are a separate, homogeneous population with the same $\mathrm{MCH}$ as non-F cells. ${ }^{\S}$ Percent $\mathrm{HbF}$ in transferrin receptor-positive cells. ${ }^{\|}$Ratio of percent $\mathrm{HbF}$ in all $\mathrm{RBC}$ to percent $\mathrm{HbF}_{\text {in }} \mathrm{TfR}^{+}$cells. Time for $50 \%$ removal of $\mathrm{B}$ - $\mathrm{RBC}$ from the circulation. 

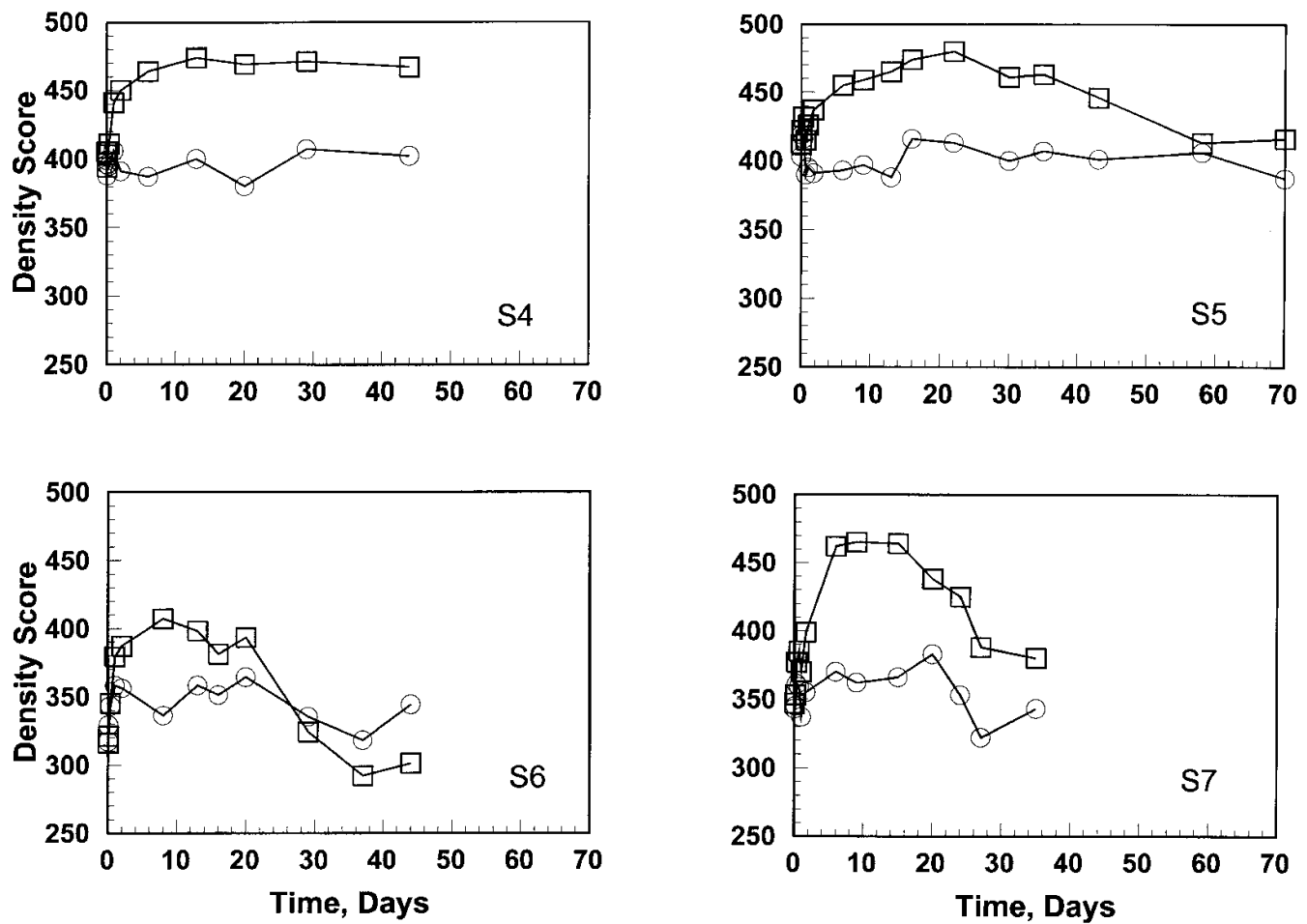

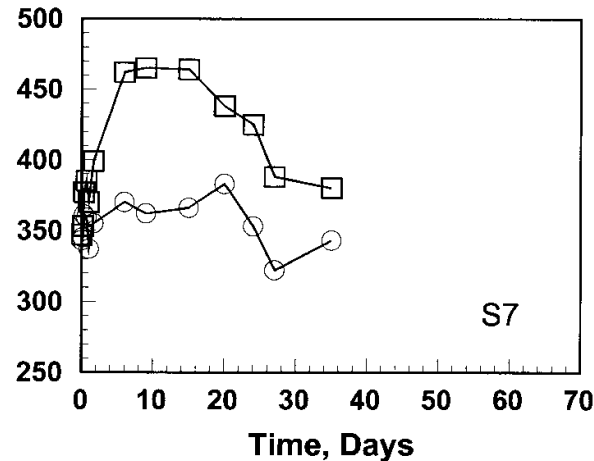

Figure 6. Time-dependent in vivo changes in the density score of biotin-labeled sickle RBC. Postinfusion blood samples were analyzed as in Fig. 5, and a density score calculated as described in Methods. For all patients there was a rapid rise in $\mathrm{B}-\mathrm{RBC}$ density (squares), followed by a period of little change, and an eventual decrease. The density scores for the unlabeled RBC at the same timepoints are also shown (circles), and remain relatively constant. $\sim 50 \%$ of the reticulocytes disappeared within $24 \mathrm{~h}$, and $\sim 75 \%$ within $48 \mathrm{~h}$.

Initial disappearance of labeled sickle cells from the circulation. In normal volunteers, the number of B-RBC after reinfusion decreased only slightly during the first $24 \mathrm{~h}$ (Table I). In patients with sickle-cell disease, however, there was a rapid loss of both biotin- and ${ }^{51} \mathrm{Cr}$-labeled cells (labels on separate cells) from the circulation in the first few hours after reinfusion (Fig. 4). This rapid loss is identical for both labels, and is therefore not due to a label-specific cellular modification. It is possible that sickle cells, but not normal cells, are damaged during in vitro manipulation, leading to the early loss of some cells regardless of the label used. Another possibility is that a variable fraction of sickle cells is sequestered in the circulation (see Discussion).

Time-dependent density changes. At various postinfusion times, cells were separated into six density fractions and each fraction was analyzed for the total number of RBC and the percentage of B-RBC. These data were analyzed both as timedependent density distributions of $\mathrm{B}-\mathrm{RBC}$ and as time-dependent changes in the absolute number of B-RBC in each fraction. The former analysis is shown in Fig. 5 for patient S5. The first column displays the density distribution of all the circulating $\mathrm{RBC}$ at the postinfusion times shown. Since this patient was clinically stable during the experimental period, there were no changes in the density distribution of all circulating RBC during this time. The second column shows the corresponding density profiles for the B-RBC. This patient has a high level of $\mathrm{HbF}$, and relatively good RBC survival (Table II). Immediately after reinfusion, the density distribution of the reinfused $\mathrm{B}-\mathrm{RBC}$ was the same as for the circulating $\mathrm{RBC}$, indicating that the in vitro procedures did not change RBC hydration. However, a time-dependent increase in the density of the reinfused B-RBC was apparent by day 2 and striking by day 6 . The DS was calculated from the density distribution at each time point for both $\mathrm{RBC}$ and $\mathrm{B}-\mathrm{RBC}$ and is plotted versus time in Fig. 6 for subjects S4-S7. HbF data and RBC survival for these patients are given in Table II. The DS for all the circulating $\mathrm{RBC}$ remained essentially constant as expected. The DS of B-RBC increased during the first week after reinfusion, remained relatively constant for a long period, and eventually decreased. The initial rapid density increase is most likely due to the maturation of young cells in the B-RBC population, including a combination of normal and pathological dehydration.

Normal RBC have a corresponding DS of $\sim 300-325$, and if a comparison is made between the density distribution of normal mature RBC and the density distribution of sickle $\mathrm{RBC}$ at least $6 \mathrm{~d}$ old (for example, B-RBC after $6 \mathrm{~d}$ in the circulation), the difference is striking (Fig. 7). The density distribution of sickle cells is often described as having a normal mean value with abnormal numbers of light and dense cells. The data in Fig. 7 show that when the contribution of young cells ( $<6 \mathrm{~d}$ old) is removed, the more uniform and severe dehydration of the remaining sickle cells is apparent.

The density distributions in Figs. 6 and 8 show the percentage of the total number of B-RBC in each fraction. An increase in the percentage of $\mathrm{B}-\mathrm{RBC}$ in a given fraction could result from either an increase in the number of cells in that fraction or a selective loss of B-RBC in other fractions. This ambiguity is overcome by calculating the absolute number of $\mathrm{B}-\mathrm{RBC}$ in each fraction. Fig. 8 shows the number of B-RBC in each fraction as a function of time for subjects $\mathrm{S} 4-\mathrm{S} 7$, based on 10,000 total (labeled plus unlabeled) RBC. Since the blood $\mathrm{RBC}$ count was stable with time, this is a measure of the absolute number of $\mathrm{B}-\mathrm{RBC}$ remaining in each density fraction in 

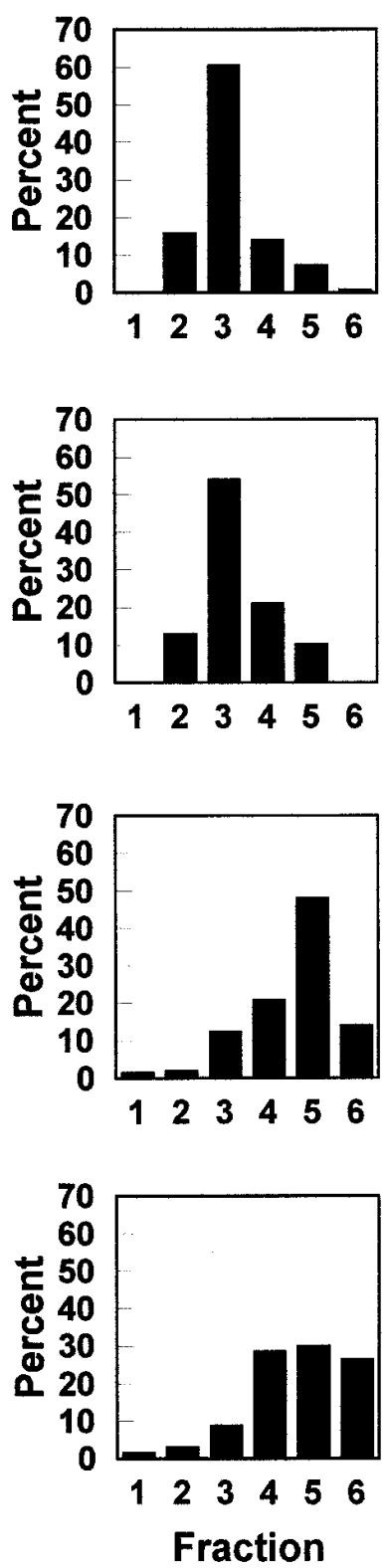

Figure 7. Comparison of the density distributions of normal RBC and sickle RBC at least $6 \mathrm{~d}$ old. Two normal AA RBC samples, in which essentially all RBC are mature, were separated into six density fractions as described in Methods. Comparison with two sickle B-RBC samples (one high $\mathrm{HbF}$ [S5] and one more typical $\mathrm{HbF}$ [S6]) containing cells at least $6 \mathrm{~d}$ old, demonstrates the marked density differences between mature normal and sickle RBC.

vivo. This analysis takes into account the falling number of $\mathrm{B}-\mathrm{RBC}$ with time, and gives some insight into the movement of labeled cells from one fraction into another. During the first several days after reinfusion, the number of $\mathrm{B}-\mathrm{RBC}$ in some fractions changed markedly. In fractions 2 and 3, the number of labeled cells decreased by at least sixty percent within three days. Fraction 4 either decreased monotonically (S4), or had a short period of increase, peaking on day 1 or day 2, before decreasing. Fraction 5 had a variable increase during the first week, with the biggest increase mirroring the decreases in fractions 3 and 4. Fraction 6 tended to remain relatively constant during the initial week and then decline. At later times, there was a general decrease in the number of B-RBC in the intermediate and dense fractions as the total number of labeled cells in the circulation was depleted. In general, these changes in the intermediate and dense fractions are consistent with a movement of cells toward higher density as they age. There was no marked, readily apparent difference in these density changes between patients with higher (S4 and S5) and lower (S6 and S7) levels of HbF.

Perhaps the most surprising part of this analysis is the essentially constant number of B-RBC in the very light fractions 1 and 2 for all subjects after the first several days. The presence of these cells at all times after reinfusion indicates that they include older cells. Two-color flow cytometric studies performed on fraction 2 (biotin/glycophorin A and biotin/CD2, data not shown) confirmed that these were RBC and that they had not floated to the top of the gradient as part of a complex with $\mathrm{T}$ lymphocytes (22). There are at least two possibilities to explain their presence. First, they may have been present at the time of labeling, and continue to circulate for a long period of time after reinfusion. This seems unlikely since there is no decrease in their number with time (after the first few days) and also since their increased hydration (very low density) suggests compromised volume regulation. The second possibility is that these older, light, labeled RBC have a relatively short survival in the circulation, but are continuously formed from RBC in the denser fractions so that a stable equilibrium is maintained.

Time-dependent changes in the $\mathrm{HbF}$ content of isolated sickle $B-R B C$. It has been assumed, based on indirect evidence, that $\mathrm{F}$ cells have a longer in vivo lifespan than non-F cells in patients with sickle-cell disease. To directly and independently follow the survival of biotinylated $\mathrm{F}$ and non-F cells, it is necessary to identify the B-RBC cells in the circulation at various times after reinfusion and then determine what percentage of the B-RBC are F cells. Fig. $9 A$ shows the timedependent change in the percentage of $\mathrm{HbF}$ in magnetically isolated $\mathrm{B}-\mathrm{RBC}$ for one patient with high $\mathrm{HbF}$ (S5) and two with lower $\mathrm{HbF}$ (S6, S7). There is clearly an increase with time in the circulation, indicating that $\mathrm{F}$ cells indeed have a better survival. These data were transformed to $\mathrm{F}$ cell percentages (Fig. $9 \mathrm{~B}$ ) and then survival curves for the two cell types (Fig. $9 C$ ) were calculated using the value for $\mathrm{HbF} / \mathrm{F}$ cell derived from the $\mathrm{HbF}$ and $\mathrm{F}$ cell percentages in unlabeled cells for each patient as described in Table II. This analysis assumes that there is no survival selection among $F$ cells based on the amount of $\mathrm{HbF}$ they contain, which undoubtedly varies to some extent.

\section{Discussion}

The data from this study indicate that a biotin label gives RBC survival characteristics that are comparable to those obtained with a concurrent ${ }^{51} \mathrm{Cr}$ label for both normal volunteers and patients with sickle-cell disease. The biotin label has a number of advantages when compared with ${ }^{51} \mathrm{Cr}$, including the lack of radioactivity, inexpensive and stable reagents, little or no elution from RBC in the circulation, multiparameter analysis on a cell-by-cell basis, and recovery of labeled RBC after a period of time in the circulation. The multiparameter capability of the biotin label is demonstrated by the reticulocyte disappearance rates presented here, which to our knowledge are the first direct measurements for autologous human reticulocytes. The 
S4
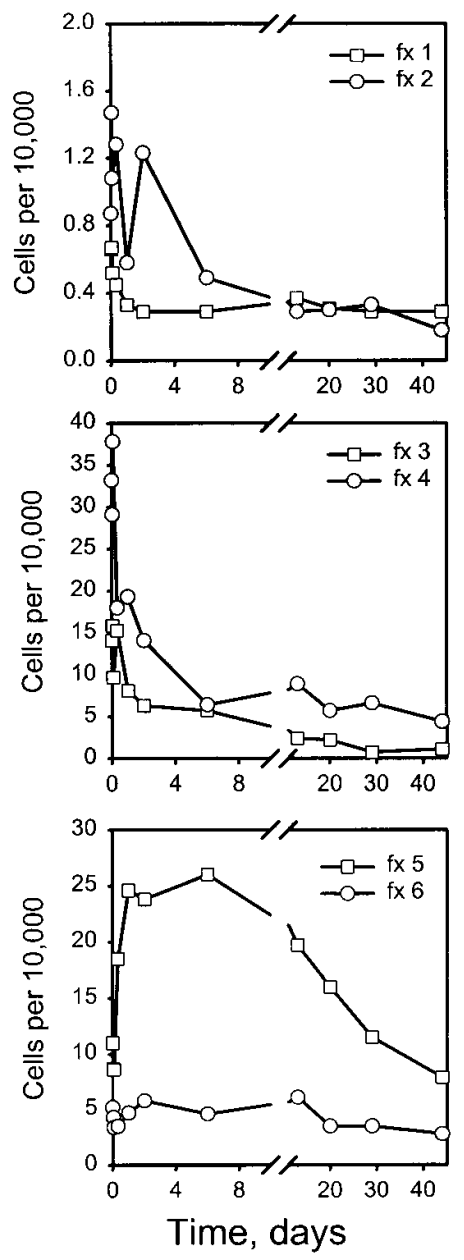

S5
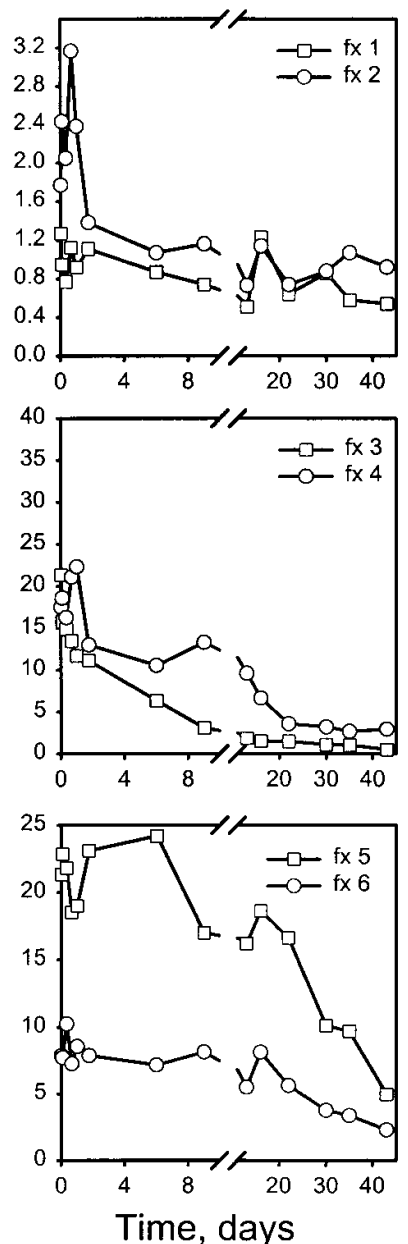

S6
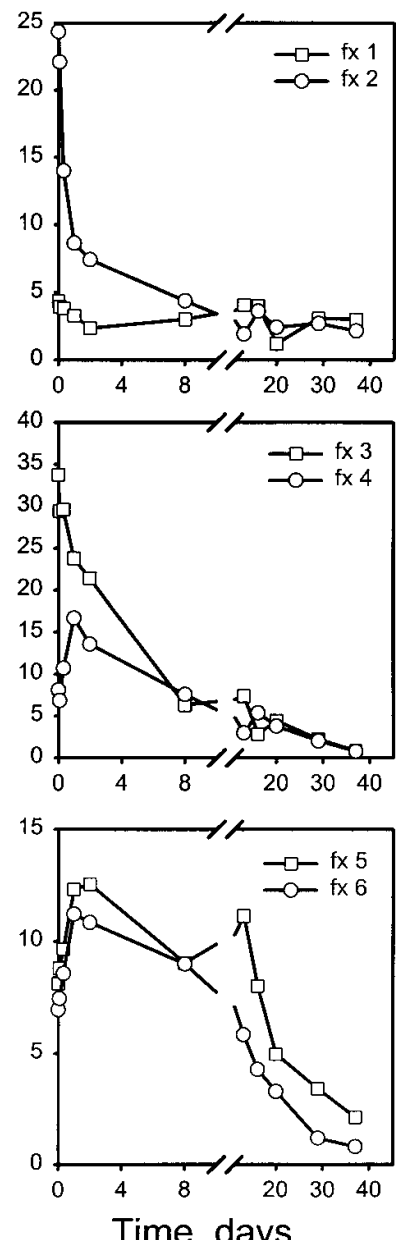

S7
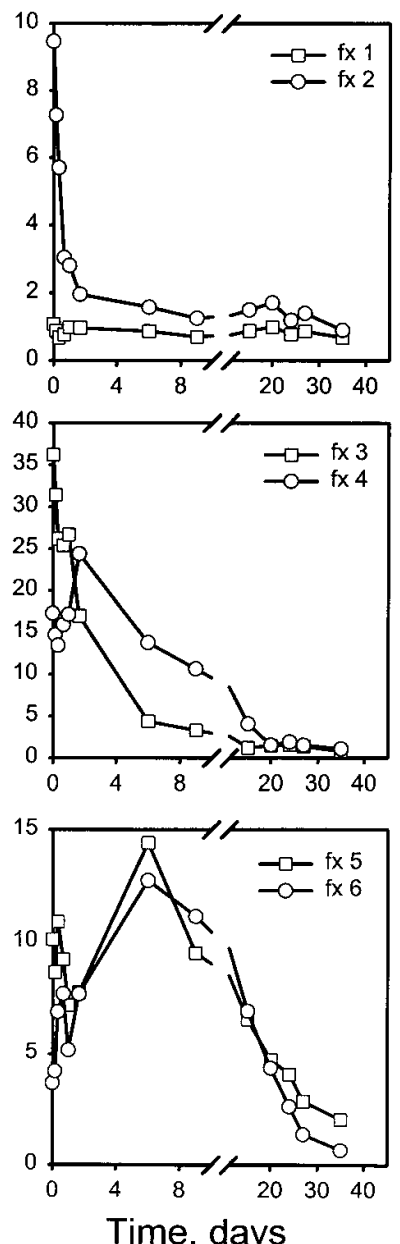

Figure 8. In vivo time-dependent changes in the absolute number of biotin-labeled sickle RBC in each density fraction. For four sickle cell patients (S4-S7), postinfusion blood samples were fractionated by density and the absolute number of B-RBC in each fraction, per 10,000 RBC loaded onto the gradient, was determined. Note that the scale for the $y$-axis varies, since the number of B-RBC in the various fractions differed substantially among patients.

results are consistent with indirect radioiron data for anemic subjects $(23,24)$ and with survival of reticulocytes from donor blood (25). In these studies it is not possible to distinguish between removal of reticulocytes from the circulation due to dehydration and sickling and the normal progression of reticulocytes to mature RBC. However, it is clear that sickle reticulocytes require $2-3$ d to complete the transition to mature RBC.

The postinfusion decrease in the number of circulating labeled sickle RBC (but not normal RBC) during the first few hours after reinfusion is noteworthy. In patient $\mathrm{S} 3, \sim 30 \%$ percent of the RBC were not detectable after $6 \mathrm{~h}$. This phenomenon appears to be distinct from the two-phase disappearance of sickle cells seen previously in some patients (26), since in those cases the first phase continued for many days (26). Both the rate and number of cells disappearing in the first few hours were identical for both labels, indicating that this phenomenon was independent of the label used. It could be due to sickle $\mathrm{RBC}$ that were hypersensitive to ex vivo handling during la- beling, and are therefore either lysed or sequestered shortly after reinfusion, but this is made less likely by the lack of effect of the higher number of cell washes required with the biotin label compared with ${ }^{51} \mathrm{Cr}$. Another possibility is the presence of a compartment of immobilized sickle RBC that exchanges with the circulating RBC. Labeled cells would enter this compartment after reinfusion and reach equilibrium at a time that reflects the exchange rate between circulating and immobilized cells. The data in Fig. 4 indicate that in at least some patients this is a relatively slow process taking several hours. Aldrich et al. (27) have recently shown that sickle cells are retained in isolated, hypoxic rat lungs. The retained cells, which came preferentially from the dense population, were released upon oxygenation, indicating a mechanical trapping of nondeformable cells. An earlier study by Castro et al. (28) also showed reversible, oxygen-dependent sequestration of sickle cells in vivo. It is possible that this mechanism, in lungs and perhaps other organs, could contribute to the short-term disappearance of labeled sickle cells. If this short-term removal 
A

S5
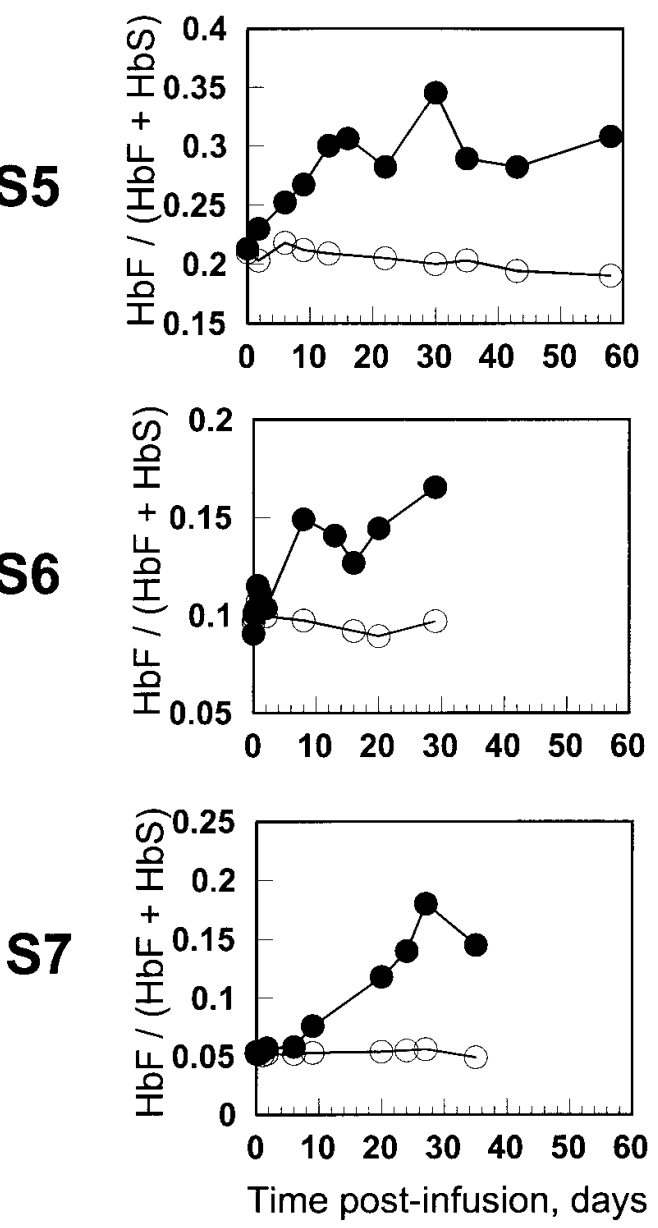
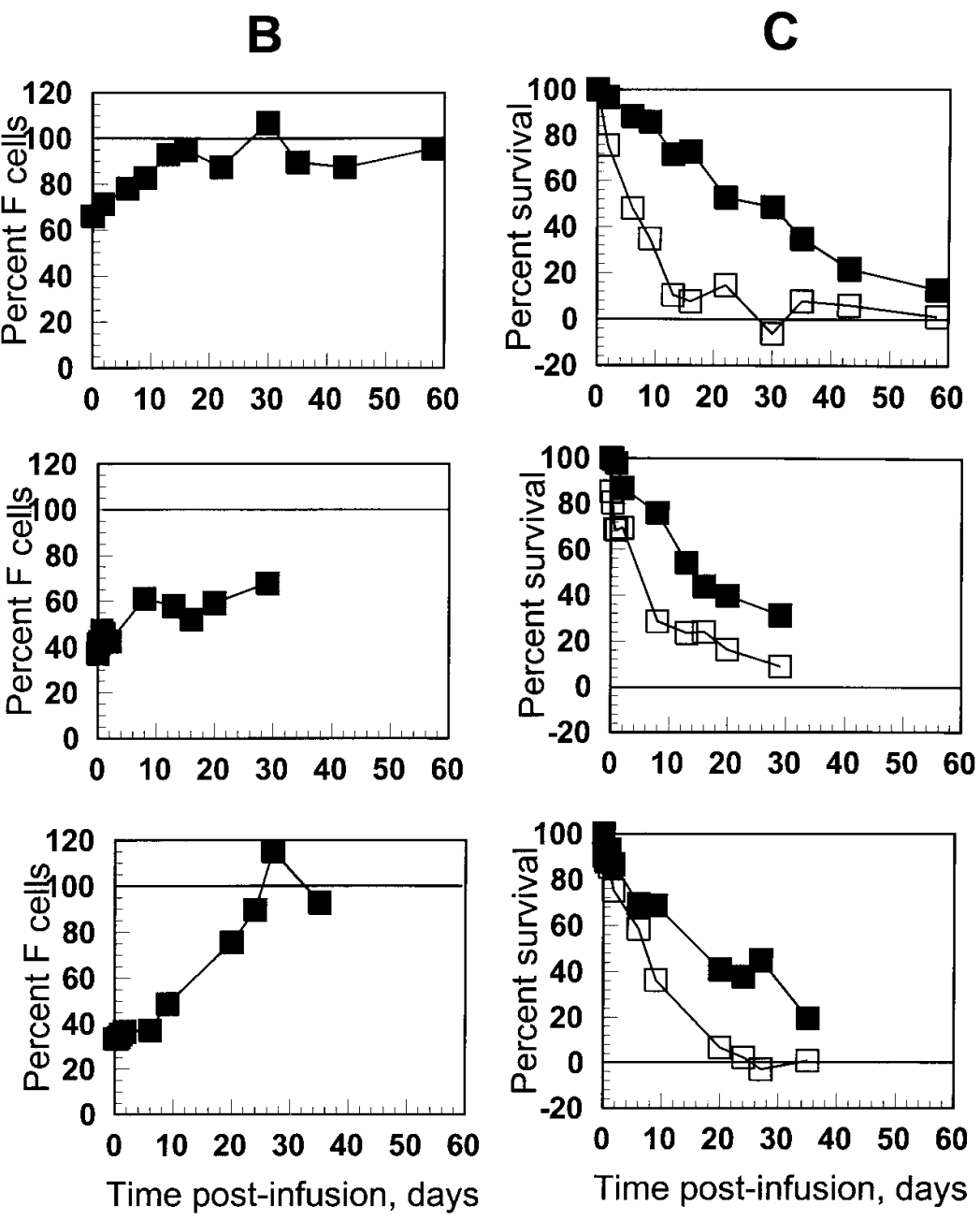

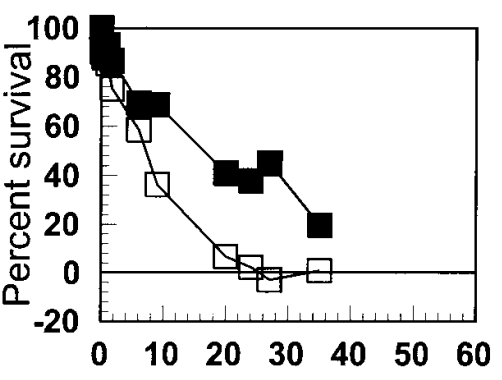

Time post-infusion, days

Figure 9. Lifespan of F cells and non-F cells. For three sickle cell patients (S5-S7), B-RBC were isolated from postinfusion blood samples with streptavidin-coated magnetic beads and analyzed for $\mathrm{HbF}$. $(A)$ The fraction of $\mathrm{HbF}$ in all the $\mathrm{RBC}$ (open circles) and in $\mathrm{B}-\mathrm{RBC}$ (closed circles) as a function of time since reinfusion; $(B)$ transformation to the percent $\mathrm{F}$ cells using the value for F/F cell from Table II for each patient; $(C)$ transformation to survival curves for $\mathrm{F}$ (closed squares) and non-F (open squares) cells using the overall survival data and the percent $\mathrm{F}$ cells at each timepoint.

was selective for F cells or dense cells, then we would expect to see a rapid change in the percentages of these cell types among the B-RBC during the first few hours after reinfusion. Shortterm changes of this type were not apparent in the patients who had B-RBC density and HbF studies, although these studies were not available for the patients with the largest shortterm B-RBC decreases.

When B-RBC were reinfused, the initial density distribution was essentially identical to that of the circulating RBC. In the first days after reinfusion, there was a shift toward the more dense fractions. These changes were complete within 4-6 d, and most likely represent changes in the hydration state of young cells. The in vivo density changes in the current study are consistent with those observed by Bertles and Milner (3), who labeled sickle $\mathrm{RBC}$ randomly with ${ }^{51} \mathrm{Cr}$ and also performed cohort studies by labeling sickle reticulocytes with $\left[{ }^{75} \mathrm{Se}\right]$ selenomethionine or ${ }^{3} \mathrm{H}$-amino acids. The true hydration state of mature sickle RBC is better represented by the density distribution of $\mathrm{B}-\mathrm{RBC}$ after $6 \mathrm{~d}$ in the circulation, and as shown in Fig. 7 is even more abnormal than indicated by all the circulating RBC. Density studies included two patients with high levels of blood $\mathrm{HbF}, \sim 20 \%$, and two patients with more typical levels. However, there were no immediately apparent differences between these two groups in the rate of density increase after reinfusion or the degree of dehydration of the mature $\mathrm{RBC}$ after a few days in the circulation. A surprising result of this analysis is the lack of a continuing increase in density score (with the possible exception of patient S5) after the first week. This implies that either (i) hydration is stable in older cells, or (ii) dehydration occurs very quickly in older cells, perhaps due to positive feedback between dehydration and sickling, leading to the fast removal of cells that enter this feedback loop, with little change in the density score of the surviving cells. After an extended time in the circulation, when relatively few labeled cells remain, the density score of the remaining B-RBC tended to decrease. One factor in this is the constant number of cells in fractions 1 and 2. Since the numbers of cells in the other fractions decrease with time, fractions 
1 and 2 eventually become a larger part of the total, thus decreasing the density score.

After the first few days, there was a constant number of B-RBC in fractions 1 and 2. Since the most likely explanation for this is a constant renewal of light cells from the denser fractions, this finding may have important implications concerning the mechanism for removal of sickle, and perhaps normal, cells from the circulation.

The studies with $\mathrm{HbF}$ and $\mathrm{F}$ cells are the first quantitation of the effect of this hemoglobin on the survival characteristics of circulating sickle cells. As expected, $\mathrm{HbF}$ was enriched in the B-RBC as they aged in the circulation. Patients S5 and S6 had an immediate $\mathrm{HbF}$ enrichment after reinfusion that leveled off after 10-15 d. Patient S7 had little enrichment the first week after reinfusion, and then $\mathrm{HbF}$ increased over the next 15-20 days. The reason for this delay is not readily apparent, but may be related to the lower F/F cell in this patient (Table II). Nevertheless, when these F cell data were transformed to lifespan for $\mathrm{F}$ and non-F cells, all three patients gave similar results (Fig. 9). If the cell survival data in Fig. 9 is extrapolated from the steep portion of the curve to the $x$-intercept, then the estimated lifespan of a cell that does not contain $\mathrm{HbF}$ is $\sim 2$ wk. This does not appear to depend on the level of circulating HbF. Similarly, the lifespan of F cells is $\sim 6-8$ wk. Previous studies $(3,4)$ have shown that there are many F cells in the denser fractions, and in the studies presented here, the density of $\mathrm{B}-\mathrm{RBC}$ is high at times most of the remaining cells are $\mathrm{F}$ cells (Figs. 6 and 9). Therefore, it appears that $F$ cells become dehydrated but nevertheless have a lifespan that is significantly greater than non-F sickle cells, presumably due to their decreased tendency to sickle even when dehydrated. These direct measurements of longer $F$ cell survival are consistent with indirect estimates based on enrichment of $\mathrm{HbF}$ in older cells when compared to reticulocytes. However, F cells do not survive normally and have a lifespan about one-half that of normal cells. Therefore, strategies to increase RBC hydration would most likely improve the survival of both $\mathrm{F}$ and non-F cells, and depending on the relative effect, may or may not change the percentage of $\mathrm{HbF}$ in the blood.

\section{Acknowledgments}

This work was supported by National Institutes of Health grants RO1 HL-51174 and MO1 RR-08084 (General Clinical Research Center).

\section{References}

1. d'Onofrio, G., R. Chirillo, G. Zini, G. Caenaro, M. Tommasi, and G. Micciulli. 1995. Simultaneous measurement of reticulocyte and red blood cell indices in healthy subjects and patients with microcytic and macrocytic anemia. Blood. 85:818-823.

2. Ballas, S.K., and E.D. Smith. 1992. Red blood cell changes during the evolution of the sickle cell painful crisis. Blood. 79:2154-2163.

3. Bertles, J.F., and P.F.A. Milner. 1968. Irreversibly sickled erythrocytes: a consequence of the heterogeneous distribution of hemoglobin types in sicklecell anemia. J. Clin. Invest. 47:1731-1741.
4. Franco, R.S., R. Barker-Gear, M.A. Miller, S.M. Williams, C.H. Joiner, and D.L. Rucknagel. 1994. Fetal hemoglobin and potassium in isolated transferrin receptor-positive dense sickle reticulocytes. Blood. 84:2013-2020.

5. Dover, G.J., S.H. Boyer, S. Charache, and M.S. Heintzelman. 1978. Individual variation in the production and survival of $\mathrm{F}$ cells in sickle-cell disease. N. Engl. J. Med. 299:1428-1435.

6. Goldberg, M.A., C. Brugnara, G.J. Dover, L. Schapira, L. Lacroix, and H.F. Bunn. 1992. Hydroxyurea and erythropoietin therapy in sickle cell anemia. Semin. Oncol. 19:74-81.

7. Zimran, A., L. Forman, T. Suzuki, G.L. Dale, and E. Beutler. 1990. In vivo aging of red cell enzymes: study of biotinylated red blood cells in rabbits. Am. J. Hematol. 33:249-254

8. Waugh, R.E., M. Narla, C.W. Jackson, T.J. Mueller, T. Suzuki, and G.L. Dale. 1992. Rheologic properties of senescent erythrocytes: loss of surface area and volume with red blood cell age. Blood. 79:1351-1358.

9. Dale, G.L., and S.L. Norenberg. 1990. Density fractionation of erythrocytes by percoll/hypaque results in only a slight enrichment for aged cells. Biochim. Biophys. Acta. 1036:183-187.

10. Suzuki, T., and G.L. Dale. 1988. Senescent erythrocytes: Isolation of in vivo aged cells and their biochemical characteristics. Proc. Natl. Acad. Sci. 85: 1647-1651.

11. Suzuki, T., and G.L. Dale. 1989. Membrane proteins in senescent erythrocytes. Biochem. J. 257:37-41.

12. Dale, G.L., R.B. Daniels, J. Beckman, and S.L. Norenberg. 1991. Characterization of senescent red cells from the rabbit. In Red Blood Cell Aging. M. Magnani and A. DeFlora, editors. Plenum Press, New York. 93-103.

13. Dale, G.L., and R.B. Daniels. 1991. Quantitation of immunoglobulin associated with senescent erythrocytes from the rabbit. Blood. 77:1096-1099.

14. Russo, V., R. Barker-Gear, R. Gates, and R. Franco. 1992. Studies with biotinylated RBC: (1) use of flow cytometry to determine posttransfusion survival and (2) isolation using streptavidin conjugated magnetic beads. $A d v$. Exp. Med. Biol. 326:101-107.

15. Hoffman-Fezwe, G., J. Mysliwietz, W. Mortlbauer, H.J. Zeitler, E. Eberle, U. Honle, and S. Thierfelder. 1993. Biotin labeling as an alternative nonradioactive approach to determination of red cell survival. Ann. Hematol. 67:81-87.

16. Christian, J.A., A.H. Rebar, G.D. Boon, and P.S. Low. 1993. Senescence of canine biotinylated erythrocytes: increased autologous immunoglobulin binding occurs on erythrocytes aged in vivo for 104 to 110 days. Blood. 82: 3469-3473.

17. Cavill, I., D. Trevett, J. Fisher, and T. Hoy. 1988. The measurement of the total volume of red cells in man: a non-radioactive approach using biotin. Br. J. Haematol. 70:491-493.

18. International Committee for Standardization in Haematology. 1980. Recommended methods for measurement of red-cell and plasma volume. $J$. Nucl. Med. 21:793-800.

19. Mollison, P.L., C.P. Engelfriet, and M. Contreras. 1987. Blood volume. In Blood Transfusion in Clinical Medicine. Blackwell, Oxford. 68-94.

20. Franco, R.S., M. Palascak, H. Thompson, and C.H. Joiner. 1995. KCl cotransport activity in light versus dense transferrin receptor-positive sickle reticulocytes. J. Clin. Invest. 95:2573-2580.

21. Campbell, T.A., R.E. Ware, and M. Mason. 1997. Detection of hemoglobins in erythrocytes by flow cytometry. Blood. 90:126a (abstr.)

22. Golan, D.E., H.S. Thatte, and A.C. Bageac. 1996. Sickle red blood cells adhere to autologous activated $\mathrm{T}$ helper lymphocytes in vivo: correlation with pain crisis in sickle cell anemia. Blood. 88:649a (abstr.)

23. Papayannopoulou, T., and C.A. Finch. 1975. Radioiron measurements of red cell maturation. Blood Cells. 1:535-546.

24. Hillman, R.S. 1969. Characteristics of marrow production and reticulocyte maturation in normal man in response to anemia. J. Clin. Invest. 48:443-453.

25. Perry, E.S., R.H. Moore, T.A. Berger, L.C. Billups, D.A. Maybee, K.F. Salata, and L.E. Lippert. 1996. In vitro and in vivo persistence of reticulocytes from donor red cells. Transfusion. 36:318-321.

26. McCurdy, P.R. 1969. ${ }^{32} \mathrm{DFP}$ and ${ }^{51} \mathrm{Cr}$ for measurement of red cell life span in abnormal hemoglobin syndromes. Blood. 33:214-224.

27. Aldrich, T.K., S.K. Dhuper, N.S. Patwa, E. Makolo, S.M. Suzuka, S.A. Najeebi, S. Santhanakrishnan, R.L. Nagel, and M.E. Fabry. 1996. Pulmonary entrapment of sickle cells: the role of regional alveolar hypoxia. J. Appl. Physiol. 80:531-539.

28. Castro, O., G.W. Osbaldiston, L. Aponte, R. Roth, J. Orlin, and S.C Finch. 1976. Oxygen-dependent circulation of sickle erythrocytes. J. Lab. Clin. Med. 88:732-744. 